\title{
Developing a core competency model for translational medicine curriculum
}

\author{
Hyun Bae Yoon ${ }^{1}$, Do Joon Park ${ }^{2,3,4}$, Jwa-Seop Shin ${ }^{5}$ and Curie Ahn ${ }^{2,3}$ \\ ${ }^{1}$ Office of Medical Education, Departments of ${ }^{2}$ Internal Medicine and ${ }^{3}$ Translational Medicine, Seoul National \\ University College of Medicine, Seoul, ${ }^{4}$ Office of Director, Korea National Institute of Health, Cheongju, and \\ ${ }^{5}$ Department of Medical Education, Seoul National University College of Medicine, Seoul, Korea
}

Purpose: This study aimed to develop a core competency model for translational medicine curriculum in the Korean graduate education context.

Methods: We invited specialists and key stakeholders to develop a consensus on a core competency model. The working group composed of 17 specialists made an initial draft of a core competency model based on the literature review. The initial draft was sent to the survey group by email to ask whether they agreed or disagreed with each core competency. The working group simplified, merged, or excluded the competencies that received less than $80 \%$ agreement among the 43 survey respondents. The working group also reorganized the order of the domains and competencies based on the survey results, and clustered the domains into four major areas.

Results: The final core competency model has four areas, 12 domains, and 34 core competencies. The major areas are theory-based problem assessment and formulation, study design and measurement, study implementation, and literature review and critique. Conclusion: This new core competency model will provide guidance for the competency based education of translational medicine in Korea.

Key Words: Competency-based education, Curriculum, Translational medical research

\section{Introduction}

Over the last few decades, the translation of basic scientific discoveries into clinical applications and public health improvements has become a major focus in biomedical research [1]. Translational medicine research fosters the multidirectional integration of basic science, clinical medicine, and population-based approach, to ultimately improve the health of the public [2]. The concept and the role of translational medicine research has been more clearly defined by the Clinical and Translational Science Award (CTSA) community in recent years. The CTSA Education and Career Development Key Function Committee collaborated over several years to identify 14 thematic areas of core competencies for clinical and translational medicine research [3]. These core competencies let the directors of translational medicine degree programs to be sure that their curriculum is comprehensive and that the students achieve these competencies through their training programs [4].

However, the CTSA core competencies which were
Received: June 6, 2018 • Revised: July 9, 2018 • Accepted: July 18, 2018 Corresponding Author: Curie Ahn (https://orcid.org/0000-0001-7033-1102) Department of Internal Medicine, Seoul National University College of Medicine, 103 Daehak-ro, Jongno-gu, Seoul 03080, Korea

Tel: +82.2.740.8418 Fax: +82.2.741.1186 email: curie@snu.ac.kr
Korean J Med Educ 2018 Sep; 30(3): 243-256.

https://doi.org/10.3946/kjme.2018.99

eISSN: 2005-7288

(C) The Korean Society of Medical Education. All rights reserved. This is an open-access article distributed under the terms of the Creative Commons Attribution Non-Commercial License (http:// creativecommons.org/licenses/by-nc/3.0/), which permits unrestricted non-commercial use, distribution, and reproduction in any medium, provided the original work is properly cited. 
developed in the context of the United States of America cannot be directly applied to other countries throughout the world due to their different system, contexts and cultural backgrounds. In the Korean academy, core competencies for translational medicine curriculum have not yet been clearly defined. Without a clear definition, developers of translational medicine curriculum will struggle to define specific program objectives, to specify the knowledge and skills that trainees are expected to develop, to select appropriate teaching and learning methods, and to assess whether competencies are achieved [2].

This study aimed to develop a core competency model for translational medicine curriculum in the Korean graduate education context. If we intend to develop a clear and valid model that is widely accepted within the Korean academy, a consensus should exist among the specialists and key stakeholders involved in the field of translational medicine research in Korea. This study invited specialists and key stakeholders to develop a consensus on a core competency model.

\section{Methods}

\section{Working group}

Seventeen specialists were invited to take part in the working group. Most of them were translational medicine specialists with medical background from the Department of Translational Medicine of a single medical college. Two other specialists who had both medical background and doctor of philosophy in education were from the Department of Medical Education at the same institution. Most of the members of the working group were also included in the survey group later.

\section{Survey group}

Translational medicine specialists and key stakeholders were invited to participate in the survey group to collect their ideas and arrive at a consensus on the core competencies of translational medicine research. Eighty specialists engaging in translational medicine research at a single medical college made up most of the survey group. Twenty-five other specialists and key stakeholders from different colleges, universities, and research institutions in Korea were also added to the list. They survey results were collected only from the participants who agreed with the purpose of the survey.

\section{Process}

First, the working group reviewed previous studies on core competencies and training programs for clinical and translational medicine research from global perspectives [3,5-7]. Then, the working group made an initial draft of the core competency model in English based on the literature review. The initial draft was sent to the survey group by email to ask whether they agreed or disagreed with each core competency. The survey group was also allowed to propose new competencies that were not listed on the initial draft. The email was sent 3 times or until a reply was received. Opinions on each domain of core competencies were also collected through the survey. After the survey, the working group simplified, merged, or excluded the competencies that received less than $80 \%$ agreement among the survey respondents. The working group also reorganized the order of the domains and competencies based on the survey results, and clustered the domains into four major areas. Finally, the working group made a list of specific competencies for each core competency that describe the core competencies in detail. The English version of the core competency model was translated into Korean by the working group. 
Hyun Bae Yoon, et al: Competency model for translational medicine curriculum

\section{Results}

\section{Initial draft and survey results}

The initial draft had 13 domains and 46 core com- petencies. $41 \%$ (43 out of 105) of the survey group responded to the survey. Thirty-five specialists from a single medical college and eight specialists from other institutions responded to the survey on the initial draft (Table 1). Eighty percent (36 out of 46) of the initial core competencies received an agreement from above

\begin{tabular}{|c|c|c|}
\hline Domains & Core competencies & $\begin{array}{c}\text { Agreement } \\
|\%|\end{array}$ \\
\hline \multirow{4}{*}{$\begin{array}{l}\text { 1. Theory-based } \\
\text { problem } \\
\text { assessment and } \\
\text { formulation }\end{array}$} & 1. Identify major clinical/public health problems and relevant translational research questions & 100 \\
\hline & 2. Formulate sound hypotheses & 95 \\
\hline & 3. Develop innovative, testable clinical and translational research questions & 93 \\
\hline & 4. Extract information from the scientific literature that yields scientific insight for research innovation & 95 \\
\hline \multirow[t]{5}{*}{$\begin{array}{l}\text { 2. Study design and } \\
\text { measurement }\end{array}$} & $\begin{array}{l}\text { 1. Formulate a well-defined clinical or translational research question to be studied in human or } \\
\text { animal models }\end{array}$ & 88 \\
\hline & $\begin{array}{l}\text { 2. Propose study designs for addressing a clinical or translational research question, and assess } \\
\text { the strengths and weaknesses of possible study designs for a given clinical or translational research } \\
\text { question }\end{array}$ & 93 \\
\hline & 3. Design appropriate, ethically sound, and hypothesis-driven clinical studies & 95 \\
\hline & 4. Identify important outcome measures for incorporation into patient-oriented clinical trial design & 93 \\
\hline & 5. Manage research and development projects & 84 \\
\hline \multirow[t]{3}{*}{$\begin{array}{l}\text { 3. Study } \\
\text { implementation }\end{array}$} & $\begin{array}{l}\text { 1. Compare the feasibility, efficiency, and ability to derive unbiased inferences from different } \\
\text { translational research study designs }\end{array}$ & 95 \\
\hline & 2. Assess threats to internal validity in any planned or completed translational study & 93 \\
\hline & 3. Incorporate regulatory precepts into the design of any translational study & 86 \\
\hline \multirow{3}{*}{$\begin{array}{l}\text { 4. Literature review } \\
\text { and critique }\end{array}$} & 1. Describe the current state of knowledge about a biomedical, clinical, or public health problem & 86 \\
\hline & 2. Use evidence as the basis of the critique and interpretation of results of published studies & 95 \\
\hline & 3. Identify potential sources of bias and variation in published studies & 93 \\
\hline \multirow[t]{3}{*}{ 5. Data integration } & 1. Assess data sources and data quality to answer specific clinical or translational research questions & 95 \\
\hline & 2. Implement quality assurance and control procedures for different study designs and analysis & 93 \\
\hline & 3. Define bias in clinical and translational research & 91 \\
\hline \multirow{2}{*}{$\begin{array}{l}\text { 6. Statistical } \\
\text { approaches and } \\
\text { applications }\end{array}$} & 1. Build effective statistical expertise into research teams & 95 \\
\hline & $\begin{array}{l}\text { 2. Determine and justify the appropriate statistical technique(s) for a specific research question and } \\
\text { concomitant study design }\end{array}$ & 100 \\
\hline \multirow[t]{2}{*}{ 7. Health informatics } & $\begin{array}{l}\text { 1. Identify modern information systems for collecting, organizing, managing, and accessing clinical } \\
\text { data }\end{array}$ & 95 \\
\hline & $\begin{array}{l}\text { 2. Utilize best practices in informatics for the organization and management of biomedical/health } \\
\text { information }\end{array}$ & 86 \\
\hline \multirow{3}{*}{$\begin{array}{l}\text { 8. Preclinical drug } \\
\text { development }\end{array}$} & 1. Define drug development goals, and explain the overall process of drug development & 84 \\
\hline & $\begin{array}{l}\text { 2. Propose preclinical study designs for lead optimization, formulation developments, pharmacology } \\
\text { studies, and toxicity studies }\end{array}$ & 67 \\
\hline & $\begin{array}{l}\text { 3. Describe investigational new drug profiling, new drug application, and the requirements of theFood } \\
\text { and Drug Administration for drug and biologic products }\end{array}$ & 81 \\
\hline \multirow[t]{2}{*}{$\begin{array}{l}\text { 9. Principles of } \\
\text { medical sciences }\end{array}$} & $\begin{array}{l}\text { 1. Understand the core concepts of anatomy and physiology of body systems, and pathogenesis } \\
\text { and treatment (non-MD students) }\end{array}$ & 93 \\
\hline & 2. Understand the core concepts of basic science (MD students) & 95 \\
\hline \multirow[t]{2}{*}{$\begin{array}{l}\text { 10. Scientific } \\
\text { communication }\end{array}$} & $\begin{array}{l}\text { 1. Communicate scientific findings to your peers and to disseminate scientific knowledge, through } \\
\text { medical writing, presentations, and publications }\end{array}$ & 98 \\
\hline & 2. Assess the clinical implications of scientific information & 84 \\
\hline
\end{tabular}


Table 1. (Continued)

\begin{tabular}{|c|c|c|}
\hline Domains & Core competencies & $\begin{array}{l}\text { Agreement } \\
(\%)\end{array}$ \\
\hline \multirow{4}{*}{$\begin{array}{l}\text { 11. Translational } \\
\text { teamwork and } \\
\text { leadership }\end{array}$} & $\begin{array}{l}\text { 1. Build an interdisciplinary/intradisciplinary/multidisciplinary team that matches the objectives of } \\
\text { the research problem }\end{array}$ & 86 \\
\hline & 2. Manage an interdisciplinary team of scientists & 72 \\
\hline & 3. Demonstrate group decision-making techniques & 67 \\
\hline & 4. Participate in cross-disciplinary training and mentoring & 81 \\
\hline \multirow{5}{*}{$\begin{array}{l}\text { 12. Health technology } \\
\text { industrialization } \\
\text { and } \\
\text { entrepreneurship }\end{array}$} & $\begin{array}{l}\text { 1. Explain the utility and mechanism of commercialization for clinical and translational research findings, } \\
\text { the patent process, and technology transfer }\end{array}$ & 74 \\
\hline & 2. Transform translational idea into a high-impact venture & 63 \\
\hline & $\begin{array}{l}\text { 3. Develop the effective applications for funding from appropriate governmental and/or } \\
\text { non-governmental sources at each stage of translating research to clinical care of patients }\end{array}$ & 72 \\
\hline & $\begin{array}{l}\text { 4. Propose technology-inspired models for success, and be able to manage financial and funding } \\
\text { issues }\end{array}$ & 70 \\
\hline & $\begin{array}{l}\text { 5. Experience at least one part of the industrialization process of translational medical research } \\
\text { products such as pharmaceuticals, medical devices, or biologics }\end{array}$ & 77 \\
\hline \multirow{8}{*}{$\begin{array}{l}\text { 13. Humanities and } \\
\text { ethical principles }\end{array}$} & 1. Identify the historical issues of translational medical research & 86 \\
\hline & $\begin{array}{l}\text { 2. Understand demographic, cultural, geographic, and ethnic differences inhealth care and aim for } \\
\text { globalization }\end{array}$ & 81 \\
\hline & 3. Propose multi-disciplinary collaborations and consilience in translational medicine & 79 \\
\hline & 4. Demonstrate the knowledge of research ethicsfrom basic to clinical studies & 88 \\
\hline & $\begin{array}{l}\text { 5. Describe the requirements and processes of Food and Drug Administration approval for medicine, } \\
\text { medical supplies and devices }\end{array}$ & 84 \\
\hline & 6. Apply the principles and requirements of institutional review board approval & 100 \\
\hline & 7. Explain conflict of interest management in research & 91 \\
\hline & 8. Apply the principles of conflictsof interest accompanying research and presentations & 86 \\
\hline Average rate of agreement & & 87 \\
\hline
\end{tabular}

MD: Doctor of medicine.

\begin{tabular}{|c|c|c|}
\hline Areas & Domains & Core competencies \\
\hline \multirow[t]{2}{*}{$\begin{array}{l}\text { Humanistic and } \\
\text { collaborative } \\
\text { approach }\end{array}$} & $\begin{array}{l}\text { 1. Humanities and } \\
\text { ethical principles }\end{array}$ & $\begin{array}{l}\text { 1. Develop humanities-based consilience in translational medicine } \\
\text { 2. Demonstrate the knowledge of research ethics from basic to clinical studies } \\
\text { 3. Apply the principles of conflicts of interest accompanying research and presentations } \\
\text { 4. Apply the principles and requirements of institutional review board approval }\end{array}$ \\
\hline & $\begin{array}{l}\text { 2. Translational } \\
\text { teamwork and } \\
\text { leadership }\end{array}$ & $\begin{array}{l}\text { 1. Communicate scientific findings to your peers and to disseminate scientific knowledge, through } \\
\text { medical writing, presentations, and publications } \\
\text { 2. Build and manage an interdisciplinary/intradisciplinary/multidisciplinary team that matches } \\
\text { the objectives of the research problem } \\
\text { 3. Participate in cross-disciplinary training and mentoring }\end{array}$ \\
\hline \multirow[t]{3}{*}{$\begin{array}{l}\text { Biomedical } \\
\text { knowledge and } \\
\text { skills }\end{array}$} & $\begin{array}{l}\text { 3. Literature review } \\
\text { and critique }\end{array}$ & $\begin{array}{l}\text { 1. Describe the current state of knowledge about a biomedical, clinical, or public health problem } \\
\text { 2. Use evidence as the basis of the critique and interpretation of results of published studies } \\
\text { 3. Identify potential sources of bias and variations in published studies }\end{array}$ \\
\hline & $\begin{array}{l}\text { 4. Principles of } \\
\text { medical sciences }\end{array}$ & $\begin{array}{l}\text { 1. Understand the core concepts of anatomy and physiology of body systems, and pathogenesis } \\
\text { and treatment } \\
\text { 2. Understand the core concepts of basic science and biomedical engineering }\end{array}$ \\
\hline & $\begin{array}{l}\text { 5. Biomedical } \\
\text { informatics }\end{array}$ & $\begin{array}{l}\text { 1. Identify modern information systems for collecting, organizing, managing, and accessing } \\
\text { clinical data } \\
\text { 2. Utilize best practices in informatics for the organization and management of biomedical } \\
\text { information }\end{array}$ \\
\hline
\end{tabular}


Hyun Bae Yoon, et al: Competency model for translational medicine curriculum

\begin{tabular}{|c|c|c|}
\hline Areas & Domains & Core competencies \\
\hline \multirow[t]{6}{*}{$\begin{array}{l}\text { Translational } \\
\text { research } \\
\text { capability }\end{array}$} & $\begin{array}{l}\text { 6. Theory-based } \\
\text { problem } \\
\text { assessment and } \\
\text { formulation }\end{array}$ & $\begin{array}{l}\text { 1. Identify major clinical/public health problems and relevant translational research questions } \\
\text { 2. Develop innovative, testable clinical and translational research questions } \\
\text { 3. Formulate sound hypotheses }\end{array}$ \\
\hline & $\begin{array}{l}\text { 7. Study design and } \\
\text { outcome } \\
\text { measurement }\end{array}$ & $\begin{array}{l}\text { 2. Assess the strengths and weaknesses of possible study designs for a given clinical or translational } \\
\text { research question } \\
\text { 3. Design appropriate, ethically sound, and hypothesis-driven clinical studies } \\
\text { 4. Identify important outcome measures for incorporation into patient-oriented clinical trial } \\
\text { design }\end{array}$ \\
\hline & $\begin{array}{l}\text { 8. Study } \\
\text { implementation }\end{array}$ & $\begin{array}{l}\text { 1. Compare the feasibility, efficiency, and ability to derive unbiased inferences from different } \\
\text { translational research study designs } \\
\text { 2. Assess threats to internal validity in any planned or completed translational study } \\
\text { 3. Incorporate regulatory precepts into the design of any translational study }\end{array}$ \\
\hline & 9. Data integration & $\begin{array}{l}\text { 1. Assess data sources and data quality to answer specific clinical or translational research } \\
\text { questions } \\
\text { 2. Implement quality assurance and control procedures for different study designs and analyses } \\
\text { 3. Assess potential bias and variation of source data }\end{array}$ \\
\hline & \multirow{2}{*}{$\begin{array}{l}\text { 10. Statistical } \\
\text { approaches and } \\
\text { applications }\end{array}$} & 1. Build effective statistical expertise into research teams \\
\hline & & $\begin{array}{l}\text { 2. Determine and justify the appropriate statistical techniques for a specific research question } \\
\text { and concomitant study design }\end{array}$ \\
\hline \multirow[t]{3}{*}{$\begin{array}{l}\text { Outcome-oriented } \\
\text { approach }\end{array}$} & $\begin{array}{l}\text { 11. Biomedical } \\
\text { product } \\
\text { development }\end{array}$ & $\begin{array}{l}\text { 1. Define biomedical product development goals, and explain the overall developmental process } \\
\text { 2. Propose preclinical study designs for biomedical product development } \\
\text { 3. Describe investigational new drugprofiling, new biomedical product application, and the } \\
\text { requirements of regulatory authorities for biomedical products }\end{array}$ \\
\hline & \multirow{2}{*}{$\begin{array}{l}\text { 12. Health technology } \\
\text { industrialization } \\
\text { and } \\
\text { entrepreneurship }\end{array}$} & $\begin{array}{l}\text { 1. Explain the utility and mechanism of commercialization for clinical and translational research } \\
\text { findings, the patent process, and technology transfer }\end{array}$ \\
\hline & & $\begin{array}{l}\text { 2. Experience at least one part of the industrialization process of translational biomedical products } \\
\text { 3. Develop effective applications for funding from appropriate governmental and/or } \\
\text { nongovernmental sources at each stage of translational research }\end{array}$ \\
\hline
\end{tabular}

$80 \%$ of the survey group. The average rate of agreement with the competencies was $87 \% \pm 10 \%$. The survey respondents expressed several major opinions on the initial draft of the core competency model. First, they stated that there should be an order among the domains and competencies in the model. Many of them suggested that the domains should be aligned from the fundamental elements to the practical elements, and that the competencies in each domain should be aligned from early and basic competencies to late and more difficult competencies. Second, they pointed out that some of the competencies overlapped with each other, and could be combined. Third, they indicated that some of the competencies seemed to go beyond the scope of translational medicine research and were more related to highly specialized expertise in other specific fields.

\section{Core competency model}

The final core competency model has four areas, 12 domains, and 34 core competencies (Table 2). The major areas, domains, and competencies are aligned from the innermost, fundamental elements to the outermost practical elements. The working group developed a round target figure to symbolize this model (Fig. 1). Each core competency has two to five specific competencies that describe the core competencies in detail (Appendix 1). 
Fig. 1. The Major Four Areas and 12 Domains of the Core Competency Model

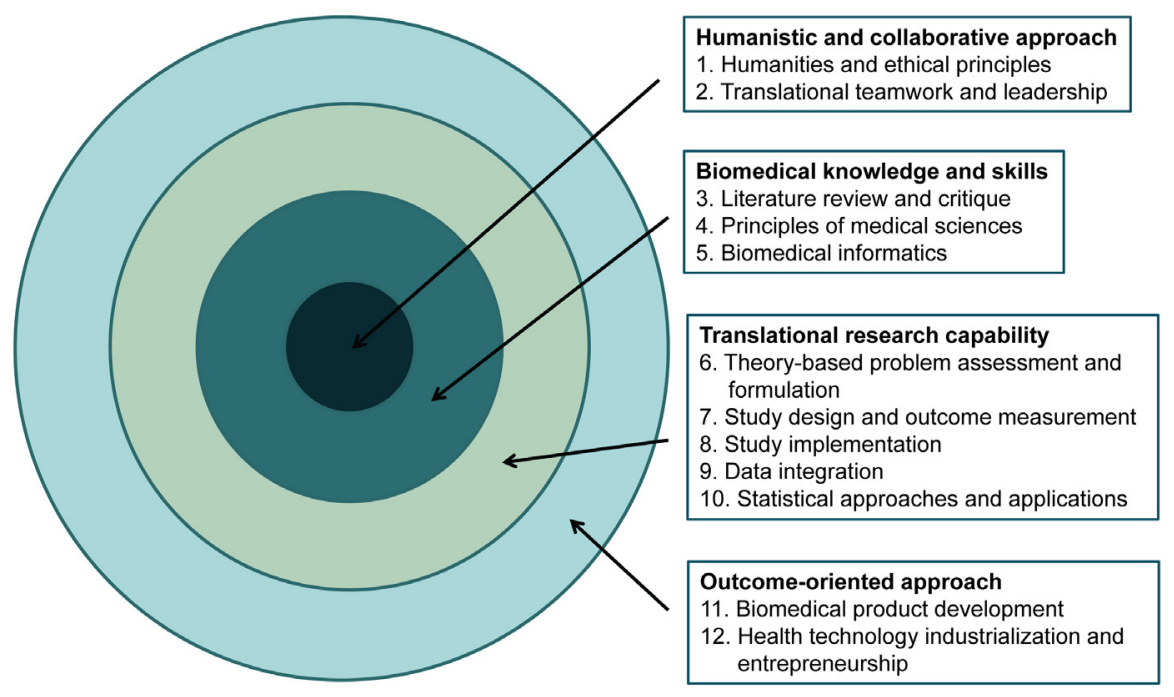

\section{Discussion}

Through this study, we were able to develop a core competency model for translational medicine curriculum in graduate education based on a consensus among the related specialists and key stakeholders in Korea. In most of the previous studies, the process to reach the consensus among the stakeholders was not clearly described $[5,8]$. This study adapted a two-step approach that was also used in a previous study, inviting the working group and a broader opinion group consecutively to reach a consensus [6].

The final core competency model has four areas, 12 domains, and 34 core competencies. Many of the domains and competencies in the Korean competency model are similar to those of other competency models in the literature. This may be due to the general concepts and common methodologies shared in biomedical research and the universal definition of translational medicine research worldwide [9]. However, there are also some differences between the Korean model and the other models. Our Korean model is structured in a more logical and systematic way. The domains are categorized into four major areas, and the major areas, domains, and competencies are aligned from the fundamental and basic elements to the practical elements. The Korean competency model also places a greater emphasis on the basic concepts and principles of medical science than other models. This may reflect the research environment in Korea, in which most translational medicine research is conducted by doctor of medicine scientists in medical institutions. Finally, there are two to five specific competencies for each core competency that describe the core competencies in detail, and the whole model is described in both English and Korean. This will help the Korean researchers and program directors understand and utilize this model.

Developing and evaluating competence within the translational medicine research field is not only important for educational needs, but also for the accountability of this field [9]. Core competencies for translational medicine research define the knowledge, skills, and attitudes needed to function successfully within this field [10,11]. Achieving competence is a developmental process that requires a gradual progression toward the integration of these knowledge, skills, and attitudes [12]. Competency-based education is 
a learning paradigm focused on what learners need to know and be able to do, based on the goals and objectives of the curriculum $[13,14]$. Thus, this new core competency model could provide guidance for the education and training of translational medicine researchers in Korea.

This study also has some limitations. We were not able to invite all the specialists and stakeholders involved in the field of translational medicine research in Korea. Most members of the working group were from a single institution, and the majority of the respondents to the survey were also from the same institution. Some of the members in the working group also participated in the survey. The last version of the core competency model was not sent to the survey group again for an eventual agreement. Thus, this core competency model should not be perceived as a final fixed version but rather as an initial version that could be revised and updated continuously. Moreover, any individual institution may adapt and modify this model according to its specific needs and circumstances.

We developed a core competency model for translational medicine curriculum in Korea through a consensus among the specialists and key stakeholders in the field. This core competency model will help the developers of translational research education and training programs to articulate specific program objectives, create an appropriate curriculum, and assess whether program objectives and competency requirements are met.

\section{ORCID:}

Hyun Bae Yoon: https://orcid.org/0000-0003-4367-5350;

Do Joon Park: https://orcid.org/0000-0001-9630-3839; Jwa-Seop Shin: https://orcid.org/0000-0002-6251-3616; Curie Ahn: https://orcid.org/0000-0001-7033-1102

Acknowledgements: None.
Funding: This research was supported by Basic Science Research Program through the National Research Foundation of Korea funded by the Ministry of Education.

Conflicts of interest: No potential conflict of interest relevant to this article was reported.

Author contributions: Conception and design of the work: HBY, DJP, JSS, CA; data collection: HBY; data analysis and interpretation: HBY, DJP, JSS, CA; statistical analysis: HBY; drafting the article: HBY; critical revision of the article: DJP, JSS, CA; receiving grant: DJP; and final approval of the version to be published: all authors.

\section{References}

1. Drolet BC, Lorenzi NM. Translational research: understanding the continuum from bench to bedside. Transl Res. 2011;157(1):1-5.

2. Rubio DM, Schoenbaum EE, Lee LS, et al. Defining translational research: implications for training. Acad Med. 2010;85(3):470-475

3. CTSA Consortium. Core competencies for clinical and translational research. https://ctsacentral.org/wp-content/ documents/CTSA\%20Core\%20Competencies_\%20final \%202011.pdf. Accessed July 6, 2017.

4. Robinson GF, Moore CG, McTigue KM, Rubio DM, Kapoor WN. Assessing competencies in a master of science in clinical research program: the comprehensive competency review. Clin Transl Sci. 2015;8(6):770-775.

5. Sonstein SA, Seltzer J, Li R, Silva H, Jones CT, Daemen E. Moving from compliance to competency: a harmonized core competency framework for the clinical research professional. J Clin Res Best Pract. 2014;28(3):17-23.

6. Poloyac SM, Empey KM, Rohan LC, et al. Core competencies for research training in the clinical pharmaceutical sciences. Am J Pharm Educ. 201 1;75(2): 27. 
7. Case Western Reserve University. $\mathrm{PhD}$ in clinical translational science. https://case.edu/facultysenate/media/ caseedu/faculty-senate/documents/approvals-and-endorse ments/spring-2014/PhDProposalTranslationalScience. pdf. Accessed July 6, 2017.

8. Woolf SH. The meaning of translational research and why it matters. JAMA. 2008;299(2):211-213.

9. Dilmore TC, Moore DW, Bjork Z. Developing a competency-based educational structure within clinical and translational science. Clin Transl Sci. 2013;6(2): 98-102.

10. Lichtenberg JW, Portnoy SM, Bebeau MJ, et al. Challenges to the assessment of competence and competencies. Prof Psychol Res Pract. 2007;38(5):474478.

11. Lee YB. The role of the concept of competence in Korean outcome-based medical education. Korean Med Educ Rev. 2013;15(3):144-150.

12. Zane TW. Domain definition: the foundation of competency assessment. Assess Update. 2008;20(1):3-4.

13. Gruppen LD. Outcome-based medical education: implications, opportunities, and challenges. Korean J Med Educ. 2012;24(4):281-285.

14. Ahn JH, Yang EB. An outcome-based approach in medical curriculum development. Korean Med Educ Rev. 2013;15(1):9-18. 
Appendix 1. The Full Version of the Core Competency Model

\begin{tabular}{|c|c|}
\hline Area & Domain \\
\hline $\begin{array}{l}\text { Humanistic and collaborative approach } \\
\text { 인문학적 협력적 접근 }\end{array}$ & $\begin{array}{l}\text { 1. Humanities and ethical principles } \\
\text { 인문학과 윤리적 원칙 } \\
\text { 2. Multidisciplinary teamwork and leadership } \\
\text { 다학제팀워크와 리더십 }\end{array}$ \\
\hline $\begin{array}{l}\text { Biomedical knowledge and skills } \\
\text { 의생명과학 지식과 기술 }\end{array}$ & $\begin{array}{l}\text { 3. Literature review and critique } \\
\text { 문헌고찰과 비평 } \\
\text { 4. Principles of medical sciences } \\
\text { 의과학의 원리 } \\
\text { 5. Biomedical informatics } \\
\text { 의료정보학 }\end{array}$ \\
\hline $\begin{array}{l}\text { Translational research capability } \\
\text { 중개의학 연구역량 }\end{array}$ & $\begin{array}{l}\text { 6. Theory-based problem assessment and formulation } \\
\text { 이론에 근거한 문제 사정과 문제 규명 } \\
\text { 7. Study design and outcome measurement } \\
\text { 연구설계와 성과 측정 } \\
\text { 8. Study implementation } \\
\text { 연구 시행 } \\
\text { 9. Data integration } \\
\text { 데이터 통합 } \\
\text { 10. Statistical approach and application } \\
\text { 통계적 접근과 적용 }\end{array}$ \\
\hline $\begin{array}{l}\text { Outcome-oriented approach } \\
\text { 결과중심 접근 }\end{array}$ & $\begin{array}{l}\text { 11. Biomedical product development } \\
\text { 의료상품 개발 } \\
\text { 12. Health technology industrialization and entrepreneurship } \\
\text { 보건 테크놀로지 산업화와 기업가 정신 }\end{array}$ \\
\hline
\end{tabular}

\section{Humanities and ethical principles: 인문학과 윤리적 원칙}

1) Develop humanities-based consilience capability in translational medicine 인문학에 바탕을 둔 통섭능력을 개발할 수 있다.

a. Interpret the principles and effects of translational medicine from the perspective of humanities and social sciences 중개의학의 원칙과 중개의학적 연구결과가 사회에 미치는 영향을 인문사회과학적 관점에서 해석할 수 있다.

b. Explain the societal burden of disease and needs of healthcare research 질병의 사회적 부담과 보건의료 연구의 필요성을 설명할 수 있다.

c. Define human and societal needs in contemporary society and find chances for translational medicine to contribute to fill the needs, combining up-to-date development of related academic areas 현재의 사회적 요구를 파악하고 관련 학문영역의 최신 지견을 종합한 중개의학 연구를 통해 그 요구를 충족시킬 기회를 발견할 수 있다.

d. Appraise the role of community engagement as a strategy for identifying community health issues, translating health research to communities 지역사회의 보건이슈를 도출하고 의학연구 결과를 지역사회에 적용하는 데 있어서 지역사회의 참여가 왜 중요한지를 설명할 수 있다.

e. Apply humanistic principles and issues to translational research design, development, implementation, and evaluation 중개의학 연구의 설계, 개발, 시행, 평가의 전 과정에 인문학적 원칙과 논점을 적용할 수 있다.

2) Demonstrate the knowledge of research ethics from basic to clinical study 기초 및 임상연구에서 연구윤리에 관한 지식을 적용할 수 있다.

a. Explain principles of biomedical ethics and be sensitive to ethical issues in translational research 생명의료윤리의 원칙을 설명하고 중개의학 연구의 윤리적 주제에 대해 민감성을 키울 수 있다.

b. Comply with regulatory guidelines for basic, clinical, and translational research 기초, 임상, 중개연구의 법률적 지침을 준수할 수 있다.

c. Analyze and interpret ethical issues in the clinical research especially with special populations, stem cell research, and genetic research 임상연구, 특히 특정 인구집단을 대상으로 한 연구, 줄기세포 연구, 유전학적 연구에 있어서 윤리적 논점을 분석하고 해석할 수 있다.

3) Apply the principles of conflict of interest accompanying research and presentation of research results 연구 및 연구결과의 발표에 있어서 이해상충의 원칙을 적용할 수 있다. 
a. Explain conflicts of interest in translational research 중개의학 연구에 있어서 이해상충을 설명할 수 있다.

b. Apply policy and standard guidelines related to commercialization of research results and intellectual property to his/her research 연구결과의 상업화, 지적 재산권의 확보에 관련된 정책과 표준지침을 자신의 연구결과에 적용할 수 있다.

4) Apply the principle and requirements of IRB approval 연구윤리 심의위원회의 원칙과 연구윤리 심의요건을 준수할 수 있다.

a. Explain the policy and standard guidelines of IRB 연구윤리 심의위원회의 정책과 표준지침을 설명할 수 있다.

b. Develop research proposal to meet the requirements of IRB 연구윤리 심의위원회의 요구조건에 맞는 연구계획서를 작성할 수 있다.

\section{Multidisciplinary teamwork and leadership: 다학제 팀워크와 리더십}

1) Communicate scientific findings to peers and disseminate knowledge through presentations, writings, and publications 과학적 발견에 대해 동료들과 의사소통하고, 발견한 지식을 발표, 저술, 출판을 통해 보급할 수 있다.

a. Comply with the principles of scientific publications including authorship, plagiarism, and conflict of interest 저작권, 표절, 이해상충 등 과학적 출판의 원칙을 준수할 수 있다.

b. Show effective communication ability with clear sentences, distinct graphic, appropriate verbal and non-verbal communication methods 명료한 문장, 명확한 그래픽, 적절한언어적, 비언어적 의사소통 기법을사용하여 효과적인 의사소통능력을 보여줄 수 있다.

2) Build and manage an intra-disciplinary/interdisciplinary/multidisciplinary team that matches the objectives of the research topic 연구주제의 목표에 적합한 학제 내/학제 간/다학제 팀을 구성하고 관리할 수 있다.

a. Explain group dynamics evolving through group journey 연구집단의 발전에 따른 그룹의 역동적 과정을 설명할 수 있다.

b. Build and lead collaborative, creative, and high-performing research team 협력적이고 창의적이며 생산적인 연구팀을 구성하고 이끌 수 있다.

c. Facilitate participatory decision-making, and lead a team to follow the collective vision 팀의 협력적 의사결정에 참여를 촉진하고 집단적 비전을 추구하도록 이끌 수 있다.

d. Manage conflict in the team and make reconciliation among conflicting members 팀 내 갈등을 관리하고 갈등 당사자 간에 조정을 이끌어낼 수 있다.

3) Participate in cross-disciplinary training and mentoring 학제 간 교육훈련과 멘토링에 참여할 수 있다.

a. Explain the strengths, weaknesses, benefits, and dangers of cross-disciplinary teamwork 학제 간 팀워크의 장점과 약점, 이득과 위험을 설명할 수 있다.

b. Practice empathetic communication in cross-disciplinary team 학제 간 팀에서 공감적 의사소통을 실천할 수 있다.

c. Participate in effective mentor-mentee relationship in layered mentoring structure 중층화된 멘토링 구조에서 효과적인 멘토-멘티 관계에 참여할 수 있다.

\section{Literature review and critique: 문헌고찰과 비평}

1) Describe the current state of knowledge about a biomedical, clinical, or public health problem 의생명과학, 임상, 보건문제에 관련된 지식의 현 상태를 기술할 수 있다.

a. Explain the way to search different electronic biomedical databases 다양한 전자 의생명과학 데이터베이스를 검색하는 방법을 설명할 수 있다.

b. Collect appropriate literatures and information systematically from the biomedical databases 의생명과학 데이터베이스로부터 적절한 문헌과 정보를 체계적으로 수집할 수 있다.

2) Use evidence as the basis of the critique and interpretation of results of published studies 과학적 근거에 기반하여 출판된 연구결과를 비평하고 해석할 수 있다.

a. Identify potential sources of bias and variations in published studies 출판된 연구에서 왜곡과 편향의 잠재적 원인을 발견할 수 있다.

b. Critically appraise the articles in terms of assessing and interpreting the evidence by systematically considering its validity, results and relevance to the area of work considered 
논문의타당성, 결과, 해당 연구영역에의 적절성을 체계적으로 고려함으로써 근거의 평가와 해석의 측면에서 논문을 비판적으로 평가할 수 있다.

4. Principles of biomedical sciences: 의생명과학의 원리

1) Explain the core concepts of anatomy and physiology of body systems, and pathogenesis and treatment in human diseases 인체의 해부 및 생리, 질병발생의 기전과 치료의 핵심개념을 설명할 수 있다.

a. Explain the basic structure of human body 인체의 기본구조를 설명할 수 있다.

b. Explain physiologic principles of human body 인체의 생리학적 원리를 설명할 수 있다.

c. Explain the basic principles of pathogenesis and treatment in human diseases 인체질병 발생기전과 치료의 기본적인 원칙을 설명할 수 있다.

2) Explain the core concepts of basic science and biomedical engineering 기초과학과 의공학의 핵심 개념을 설명할 수 있다.

a. Explain the basic principles and methods of basic science for biomedical research 의생명과학 연구를 위한 기초과학의 기본원리와 방법론을 설명할 수 있다.

b. Explainthe basic principles and applications of biomedical engineering 의공학의 기본원리와 응용방법을 설명할 수 있다.

\section{Biomedical informatics: 의료정보학}

1) Identify modern information systems for collecting, organizing, managing, and accessing clinical data 임상데이터를 수집, 조직화, 관리하고 이에 접근하기 위한 현대 정보시스템이 무엇인지를 파악할 수 있다.

a. Explain concepts of clinical information systems and databases 임상정보시스템과 데이터베이스의 개념을 설명할 수 있다.

b. Analyze and interpret clinical, molecular, and imaging information for data-driven medicine 임상, 분자생물학적, 이미지 데이터에서 유래한 정보를 분석하고 해석할 수 있다.

c. Leverage healthcare big data to profile diseases and treatments 보건의료 빅데이터를 활용하여 질병과 치료의 프로파일을 밝힐 수 있다.

2) Utilize best practices in informatics for the organization and management of biomedical information 의료정보의 조직화와 관리를 위하여 의료정보학의 모범 사례를 활용할 수 있다.

a. Explain algorithms and methods for computational biology and genomics 전산생물학과 유전체학의 알고리즘과 방법론을 설명할 수 있다.

b. Link genome scale measurements to clinical data for personalized diagnostics and therapeutics 맞춤 진단과 치료를 위하여 유전체수준의 측정치를 임상데이터와 연결할 수 있다.

c. Explain the principles and methods for pharmacogenomics 약물유전체학의 원리와 방법론을 설명할 수 있다.

\section{Theory-based problem assessment and formulation: 이론에 근거한 문제 분석과 구조화}

1) Identify major clinical and public health problems 주요 임상, 보건 문제가 무엇인지를 파악할 수 있다.

a. Explain established theories and recent questions of a specific clinical/public health/translational research topic 개개의 임상/보건/중개의학적인 연구주제에 관하여 기존에 확립된 이론과 최근의 이슈를 설명할 수 있다.

b. Investigate the academic (scientific) or social needs related to the clinical/public health topics 임상적, 보건학적 이슈와 관련된 학문적, 사회적 요구를 탐구할 수 있다.

2) Develop innovative, testable clinical and translational research questions 혁신적이고 검증 가능한 임상적, 중개의학적 연구주제를 개발할 수 있다.

a. Determine the subjects that are identified or not identified by other studies 기존 연구에 의해 확인되거나 아직 확인되지 않은 연구주제가 어떤 것인지 파악할 수 있다.

b. Assess the problems and validities of existing methods 현재 사용하고 있는 연구방법의 문제점과 유용성을 평가할 수 있다. 
c. Specify unsolved research questions for existing clinical and public health problems 임상적, 보건학적 문제에서 아직 해결되지 않은 연구 질문들을 짚어낼 수 있다.

3) Formulate sound hypotheses: 논리적인 연구가설을 수립할 수 있다.

a. Formulate an appropriate hypothesis based on established theories 기존에 확립된 이론에 근거하여 적절한 연구가설을 수립할 수 있다.

b. Find out the most feasible or novel hypothesis of the issue 연구논점에 관하여 가장 시행가능성이 높거나 참신한 연구가설을 찾아낼 수 있다.

c. Evaluate the testability of the hypotheses and defer the impracticable ones 가설의 검증가능성을 평가하고 현실성이 떨어지는 것을 유보할 수 있다.

d. Estimate the plausible results and effects of the hypothesis 연구가설로부터 도출될 예측 가능한 결과와 효과를 추정할 수 있다.

\section{Study design and outcome measurement: 연구설계와 결과측정}

1) Explain the principle and methods in study designs used in clinical and translational research 임상 및 중개연구에 사용되는 연구설계의 원리와 방법론을 설명할 수 있다.

a. Explain the study designs used in clinical and translational research 임상 및 중개연구에 사용되는 연구설계를 설명할 수 있다.

b. Assess the strengths and weaknesses of possible study designs for a given clinical or translational research question 주어진 임상 및 중개연구 주제에 맞는 연구설계의 장점과 약점을 설명할 수 있다.

c. Choose the design most appropriate to the research question 연구질문에 가장 적합한 연구설계를 선택할 수 있다.

2) Design appropriate, ethically sound, and hypothesis-driven clinical studies 윤리적이며 적절한 가설에 입각한 임상연구를 설계할 수 있다.

a. Explain statistical methods used to design and analyze clinical \& translational research projects 임상, 중개연구를 설계하고 분석하는 데 사용되는 통계적 방법을 설명할 수 있다.

b. Define exposure, outcome and confounders from research question 연구질문으로부터 노출요인, 결과변수, 교란요인을 정의할 수 있다.

c. Estimate sample size appropriate to the clinical and translational research study 임상, 중개연구에 적절한 표집의 크기를 산정할 수 있다.

d. Prepare a submission to a Research Ethics Committee 연구윤리위원회에 제출할 서류를 준비할 수 있다.

3) Identify important outcome measures for incorporation into clinical trial design 임상시험 설계에 적용할 주요 성과지표를 정의할 수 있다.

a. Explain different types of outcome measures in clinical trial design 임상시험 설계에 적용할 주요 결과지표를 정의할 수 있다.

b. Incorporate appropriate outcome measure in the clinical trial design 임상시험 설계에 적절한 결과지표를 도입할 수 있다.

8. Study implementation: 연구 시행

1) Compare the feasibility, efficiency, and ability to derive unbiased inferences from different translational research study designs 다양한 중개의학 연구설계들의 실행가능성, 효율성, 편향 없는 추론 도출 가능성을 비교할 수 있다.

a. Abstract key concepts from different translational researches 다양한 중개연구들로부터 핵심개념을 추출할 수 있다.

b. Summarize and report key results from different translational researches 다양한 중개연구들의 핵심결과들을 요약하여 보고할 수 있다.

2) Assess threats to internal validity in any planned or completed translational study 계획되거나 완료된 중개연구의 내적 타당도를 위협하는 요인을 평가할 수 있다.

a. Explain the concept of bias in translational study 중개연구에서 편향의 개념을 설명할 수 있다.

b. Identify bias in any completed translational study 
완료된 중개연구의 편향을 찾아낼 수 있다.

c. Avoid bias in any planned translational study

계획된 중개연구의 편향을 회피할 수 있다.

3) Incorporate regulatory precepts into the design of any translational study

중개연구 설계에 있어서 연구승인을 위한 규정을 적용할 수 있다.

a. Be familiarized with approval process by key regulatory office

주요 규제기관의 승인절차를 따를 수 있다.

9. Data integration: 데이터 통합

1) Assess data sources and quality to answer clinical and translational research questions

임상, 중개연구 질문에 대한 답을 제공할 수 있는 자료원과 자료의 질을 평가할 수 있다.

a. Explain the practical aspects of quality control in translational researches and clinical trials 중개연구와 임상시험 질 관리의 실제적 방법을 설명할 수 있다.

b. Assess potential bias and variation of data 데이터에 존재할 수 있는 왜곡과 편향을 평가할 수 있다.

c. Explain risk-based monitoring in translational researches and clinical trials 중개연구와 임상시험에서 위험기반 모니터링을 설명할 수 있다.

2) Implement data integration between different translational experiments and clinical trials

다양한 중개실험과 임상시험 간에 데이터 통합을 수행할 수 있다.

a. Explain the overall process of clinical and translational data integration 임상, 중개연구 데이터 통합의 전 과정을설명할 수 있다.

b. Explain data standards and clinical trial management platform 데이터 표준과 임상시험 관리 플랫폼을 설명할 수 있다.

c. Implement cross-trial integration and meta-analysis of study data 연구데이터의 통합과 메타분석을 수행할 수 있다.

\section{Statistical approaches and applications: 통계적 접근과 적용}

1) Explain the principles of statistical analysis 통계분석의 제반 원칙을 설명할 수 있다.

a. Be familiar with handling various statistical methods and programs and working with statisticians of various expertise 다양한 통계기법과 프로그램을 능숙하게 다룰 수 있고 다양한 분야의 통계 전문가와 협력할 수 있다.

2) Apply appropriate statistical method to specific study 특정 연구에 적합한 통계기법을 적용할 수 있다.

a. Determine and justify the appropriate statistical technique(s) for a specific research question and concomitant study design 특정 연구목적과 그에 따른 연구설계에 적합한 통계기술을 선택하고 그 정당성을 입증할 수 있다.

3) Summarize and report the statistical analysis results

통계분석 결과를 요약하여 보고할 수 있다.

a. Be familiar with summarizing, interpreting and expressing the study results 연구결과를 능숙하게 요약, 해석, 발표할수 있다.

b. Defend against the critiques on study design and statistical methods 연구설계와 통계방법에 대한 비판을 논리적으로 방어할 수 있다.

\section{Biomedical product development: 신의료상품 개발}

1) Define biomedical product development goals, and explain the overall developmental process 신의료상품 개발의 목적을 정의하고 개발의 전 과정을 설명할 수 있다.

a. Propose new biomedical product entities and define their developmental goals 신의료상품을 제안하고 개발 목적을 정의할 수 있다.

b. Participate in target identification and validation for biomedical products 신의료상품의 적용대상 규정과 검증과정에 참여할 수 있다.

c. Propose chemical lead of new drug and explain lead optimization process 
Hyun Bae Yoon, et al: Competency model for translational medicine curriculum

생화학적 선도약물을 제안하고 선도약물의 적정화 과정을 설명할 수 있다.

d. Identify new medical devices for unmet clinical needs

미충족임상요구를 위한 새로운 의료장비를 발굴할 수 있다.

2) Propose preclinical study designs for biomedical product development

신의료상품 개발을 위한 전임상 연구설계를 제안할 수 있다.

a. Select appropriate animal species and animal models of disease 질병연구에 적합한 동물종과 동물 모델을 선택할 수 있다.

b. Participate in proof of concept (POC) and toxicology studies

신의료상품의 개념검증(POC)과 독성학 연구에 참여할 수 있다.

c. Understand Good Laboratory Practice (GLP)

우수실험관리기준(GLP)을 설명할 수 있다.

3) Describe investigational new drug (IND) profiling, new biomedical product application, and the requirements from regulatory authority for biomedical product

연구용 신약, 신의료상품 지원신청, 신의료상품 관리당국의 요구조건을 기술할 수 있다.

a. Explain the overall process of IND profiling and new biomedical product application 연구용 신약의 프로파일링, 신의료상품 지원신청의 전 과정을 설명할 수 있다.

b. Explainclinical formulation design, preclinical safety data package, and manufactures of clinical supplies 임상 제조설계, 전임상 안전 데이터 패키지, 임상 제조과정을 설명할 수 있다.

c. Design human and clinical proof of concept studies

임상적 개념 검증연구를 설계할 수 있다.

d. Explain the guidance of regulatory authority for biomedical product

신의료상품 관리당국의 지침을 설명할 수 있다.

12. Health technology industrialization and entrepreneurship: 보건의료기술 산업화와 기업가 정신

1) Explain the utility and mechanism of commercialization for clinical and translational research findings, the patent process, and technology transfer

임상연구와 중개연구 결과의 상업화, 특허 절차, 기술이전의 효용성과 메커니즘을 설명할 수 있다.

a. Explain the difference in the processes between laboratory research works and commercial product manufacturing 실험실 연구와 상품 생산과정의 차이점을 설명할 수 있다.

b. Practice how to claim one's own idea in patent writing and explain domestic and international patent filing process 자신의 아이디어에 기반한 특허문서를 작성하고 국내, 국제 특허 출원의 절차를 수행할 수 있다.

c. Explain the meaning of terms in a typical form of technology transfer agreement 기술 이전 계약 표준양식에 사용되는 용어들을 설명할 수 있다.

2) Experience at least one part of industrialization process of translational biomedical products 중개의학 제품의 산업화 과정 중 적어도 한 과정을 경험할 수 있다.

a. Explain the difference in the characteristics, processes and technologies among sample, prototype, and mass production 샘플, 시제품, 대량생산의 서로 다른 특성과 절차 및 각각에 사용되는 기술을 설명할 수 있다.

b. Perform internship in industry laboratory

산업 연구소에서 인턴십을 수행할 수 있다.

3) Develop the effective applications for funding from appropriate governmental and/or non-governmental sources at each stages of translational research

중개의학 연구의 각 단계에 적합한 정부, 비정부 재원을 확보하기 위해 효과적인 제안서를 작성할 수 있다.

a. Explain standard RFP(request for proposal) and characteristics of good proposal

표준 제안요청서의 구성요건과 좋은 제안서의 특성을 설명할 수 있다.

b. Write a grant proposal for governmental funding

정부 재원 확보를 위한 연구비 제안서를 작성할 수 있다.

c. Write a grant/contract proposal for private sector funding

민간부문 재원확보를 위한 연구비/계약제안서를 작성할 수 있다. 